\title{
Menyikapi Rahasia di Balik Rasio dan Rasa pada Manusia
}

\author{
Aloi Kamarasyid \\ IAIN Syaikh Abdurrahman Siddik Bangka Belitung, Indonesia \\ aloi_kamarasyid@gmail.com
}

\begin{abstract}
The sciense of human will not able to solve all of things, according to the words of Allah: "And we are not given a science except a little", (Q.S 17/ Al-Isra': 85). Instinct of human must get a direction of Allah who is explained at his book. Unless the instinct will be wrong in its channel. The position of instinct and intelligence at Islam ethics, both are necessary to be used and dropped well by counselling and directing which are settled in Al-Qur'an and the guide of propnet Muhammad SAW.

Philosophy of Islam also bases on or follows the healthy intelligence to interpret all of problems of divinity, human and nature, because of necessity of thing is intelligence. It is either a subject or object of thinking. From it exits an active intelligence, because it is the first which is created by Allah. By intelligence we analyze and prove about truthm, to expose the scientific realities, about filling, idealism, ethics, law, aesthetics, extra sensory perception, and purity of heart.

Intelligence is a door of science. There are not all of sciences are revealed but there are obliged to be deductive by intelligence through experiment. Allah also gives Islam Religion which is an association of power of God which is given to human (command and prohibition). Islam Religion is a mercy to manage intelligence, feeling, heart and emotion of human. We are obliged to believe, to study so that we know which is comman ded and prohibited, to do and to broadcast the Islam Religion well and truly according to his instruction (Muslim Law).
\end{abstract}

Keywords; Rational, Feeling, Human. 


\section{A. Pendahuluan}

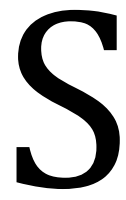

alah Allah SWT telah menciptakan langit, bumi, serta seluruh isi yang ada di dalamnya, baik yang ada di bumi maupun di luar angkasa, baik yang nyata maupun tidak nyata, baik bergerak maupun tidak bergerak, baik bernyawa maupun tidak bernyawa. Akan tetapi seluruh ciptaan Allah itu saling memiliki ciri khas yang berbeda, nama ataupun sebutan yang berbeda antara satu dengan yang lainnya, serta memiliki tugas dan kewajiban yang berbeda. Semuanya itu adalah ciptaan Allah Yang Maha Kuasa atas segala-galanya, dan apapun yang Dia mau pasti semuanya bisa terjadi. Di antara semua ciptaan Allah SWT itu ada yang diciptakan hanya untuk beribadah saja untuk selamanya (Malaikat) kepada Sang Kholik, ada juga yang menjadi pemimpin di muka bumi (fil ardhi) serta beribadah kepada-Nya yaitu mahluk-Nya yang bernama manusia, ada juga yang hanya bertujuan untuk hidup dan makan saja, yaitu hewan atau binatang.

Khusus mahluk Allah yang bernama manusia, diciptakan Allah berbeda dengan mahlukmahluk terdahulu yang lainnya, yaitu adanya insting (rasio atau akal), dan rasa (kalbu atau hati nurani). Inilah perbedaan yang paling nyata sekali dengan mahluk-mahluk lainnya. Dalam pandangan hidup kita sehari-hari, kedua alat ini harus dapat dipakai secara seimbang dan memiliki peranan yang sama pentingnya. Yang satu berkemampuan khusus dan yang satu lagi berkemampuan untuk hal-hal yang lainnya. Yang satu berkemampuan akali dan menghasilkan ilmu nomotetikal atau hukum sebab dan akibat. Yang satu lagi menghasilkan ilmu rasa atau ilmu normatif. Ilmu nomotetikal dan ilmu normatif sangat diperlukan untuk meningkatkan kesejahteraan hidup manusia, dan penggunaannya harus seimbang.

Manusia dikarunia oleh Allah SWT sebagai mahluk yang paling mulia dan sempurna, mempunyai akal pikiran (rasio) dan rasa (kalbu atau hati nurani) yang sehat. Di mana dengan akal (rasio) yang sehat manusia bisa menggunakannya seoptimal mungkin, agar lebih maju dalam berbagai bidang, dapat membuka cakrawala pikiran yang ilmiah, serta dapat digunakan untuk menimbangkan sesuatu pekerjaan mana yang baik dan mana buruk. Dengan rasa (kalbu atau hati nurani) manusia bisa memilih secara langsung mana yang lebih baik dan mana yang lebih buruk, terhadap berbagai masalah yang sedang dihadapinya, kemampuan rasa (kalbu atau hati nurani) itu tergantung kepada dirinya seseorang.

Akal (rasio) itu selalu berpatokan, sedangkan rasa (kalbu) itu tidak. Akal (rasio) itu mampu menarik implikasi, esensi, dan menyatakan sebab-akibat. Di samping itu akal mempersepsi secara kualitatif maupun kuantitatif, sedangkan kemampuan rasa terletak pada 
hubungan dunia kegaiban sebagai penangkap instuisi. Bila intuisi telah tertangkap barulah rasio melaksanakan deduksi.

Berdasarkan teori Rasional yang merupakan teori para filosof Eropa seperti Descartes (1596-1650), Immanuel Kant (1724-1804) dan lain-lain. Teori-teori tersebut terangkum dalam kepercayaan adanya dua sumber bagi konsepsi:

1. Penginderaan (sensasi). Kita mengkonsepsi panas, cahaya, rasa dan suara karena penginderaan kita terhadap semua itu.

2. Fitrah, dalam arti bahwa akal manusia memiliki pengertian-pengertian dan konsepsikonsepsi yang tidak muncul dari indera. Tetapi ia sudah ada (tetap) dalam lubuk fitrah. Jiwa menggali gagasan-gagasan tertentu dari dirinya sendiri. ${ }^{1}$

Kaum rasionalis yang menganut teori tersebut dalam menjelaskan konsepsikonsepsi manusia adalah sebagai berikut: mereka tidak mendapatkan alasan munculnya sejumlah gagasan dan konsepsi dari indera karena memang ia bukan konsepsi-konsepsi inderawi, maka ia harus digali secara esensial dari lubuk jiwa. Dari sini, jelaslah bahwa motif filosofis bagi perumusan teori rasional ini akan hilang sama sekali jika kita dapat menjelaskan secara menyakinkan konsepsi-konsepsi mental, tanpa perlu mengadaikan gagasan-gagasan fitri. Untuk itu kita dapat membantahkan teori itu melalui dua cara:

1. Menganalisis pengetahuan sedemikian sehingga dapat menisbahkan semuanya itu kepada indera dan merumuskan pemahaman mengenai cara munculnya konsepsikonsepsi dari indera. Analisis seperti ini akan membuat teori tentang ide fitri tak beralasan sama sekali, karena ia berdasarkan pemisahan total beberapa ide dari wilayah alam indera. Kalau kita dapat memperluas cakupan indera itu ke pelbagai wilayah konsepsi, maka tidak ada kebutuhan bagi konsepsi-konsepsi fitri. Cara inilah yang dianut oleh John Locke (1632-1704) untuk membantah Descartes dan kaum rasionalis lainnya. Setelah John Locke, tokoh-tokoh empirisme, seperti Berkeley (1684-1753) dan David Hume (1711-1776), memakai cara tersebut.

2. Metode filosofis untuk menolak (pandangan mengenai) konsepsi-konsepsi fitri. Ia berdasarkan atas kaidah yang menyatakan bahwa suatu kebergandaan efek tidak mungkin keluar dari sesuatu yang sederhana. Jiwa adalah sederhana. Karenanya jiwa tidak mungkin menjadi sebab fitri bagi sejumlah konsepsi dan gagasan. Adanya sejumlah besar penggalan pengetahuan dalam jiwa itu disebabkan oleh banyak

${ }^{1}$ Muhammad Ash-Shadr Baqir, Falsafatuna, (Bandung: Mizan, 2008), p. 29. 
faktor luar, yakni indera-indera instrumental dan berbagai sensasi yang terjadi padanya. $^{2}$

Suatu kritik menyeluruh atas hujah ini menuntut kita untuk menjelaskan prinsip dasar yang atasnya ia didasarkan, dan memberikan uraian tentang hakikat dan kesederhanaan jiwa. Tetapi kesempatan kita sekarang tidak mencukupi. Namun, kami harus mengisyaratkan beberapa hal berikut ini:

1. Bahwa hujah tersebut-jika dapat diterima-tak sepenuhnya menghancurkan teori tentang ide fitri. Ia hanya menunjukkan tidak adanya multiplisitas pengetahuanpengetahuan fitri, tetapi tidak membuktikan bahwa jiwa tidak secara fitri memiliki sejumlah tertentu konsepsi-konsepsi yang sesuai dengan unitas dan kesederhanaannya, dan berujung pada beberapa konsepsi lain yang tak bergantung pada indera.

2. Kami jelaskan bahwa jika teori rasional berarti adanya gagasan-gagasan fitri dalam jiwa manusia, jika hujah yang telah dikemukakan di atas dapat menolaknya dengan mengatakan, "bahwa jiwa pada esensinya adalah sederhana", maka bagaimana ia dapat melahirkan sejumlah besar gagasan-gagasan fitri? Sungguh, kalau kaum rasional benar-benar cenderung mempercayai hal itu, maka perasaan lebih dalam manusiawi kita sudah cukup untuk menolak teori mereka. ${ }^{3}$

Kita semua tahu bahwa tidak ada gagasan apapun dalam diri manusia pada saat lahirnya di muka bumi, bagaimanapun jelas dan generalnya ide itu dalam akal manusia. Allah SWT berfirman: Dan Allah yang mengeluarkan kalian dari perut-perut ibu kalian. Kalian tidak mengetahui sesuatupun. Dan Ia menjadikan bagi kalian, pendengaran dan penglihatan dan hati agar kamu semmua bersyukur (Q.S 16: 78). Tetapi ada penafsiran lain tentang teori rasionalisme ini, yakni bahwa gagasan-gagasan fitri itu ada dalam jiwa secara potensial. Ia mendapatkan sifat aktualnya dengan evaluasi dan integrasi mentah jiwa. Jadi, konsepsi-konsepsi fitri bukan bersumber dari indera. Tetapi ia dikandung oleh jiwa tanpa disadarinya. Meskipun demikian dengan integrasi jiwa ia menjadi pengetahuan dan informasi yang kita ingat kembali, lantas bangkit secara baru sama sekali, setelah (sebelumnya) ia tersembunyi dan ada secara potensial. ${ }^{4}$

2 Ibid., p. 30.

3 Ibid., p. 31.

${ }^{4}$ Ibid. 
Dalam menemukan pengetahuan, ada orang yang melalui naluri atau pandangan jauhnya menggunakan akalnya mengembangkan pemikirannya sehingga timbullah pengetahuan yang benar. Aliran filsafat yang mengembangkan pengetahuan dengan bersumber pada nalar yang dikendalikan akal ini dikenal sebagai mazhab rasionalisme. Pekarjaan mereka seolah-olah diturunkan dari cara matematikawan mengembangkan matematika dan seperangkat unsur-unsur primitif, aksioma, dan hubungan antara unsurunsur primitif itu, menjadi satu sistem (Reichenbach, 1951). Para rasionalis pertama yang dikenal dalam sejarah mungkin sekali adalah Pythagoras (kira-kira 540 SM) dan Plato (427-347 SM) yang sangat terpengaruh oleh ajaran-ajaran Pythagoras. ${ }^{5}$

Pada zaman keemasan kebudayaan Islam dikenal pada rasionalis seperti Al-Kindi (806-873 M). Walaupun berciri khas religius-spiritual, tetapi filsafat Islam juga amat bertumpu pada akal dalam menafsirkan problematika ketuhanan, manusia dan alam, karena wajib alwujud adalah akal murni. Ia adalah subyek yang berpikir sekaligus obyek pemikiran. Daripada- Nya keluar (beremansipasi) akal aktif, karena ia merupakan sesuatu pertama yang diciptakan Allah. Dalam rangkaian selanjutnya, keluar (beremansipasilah) akal-akal lain yang mengatur urusan-urusan langit, selain akan kesepuluh atau akal aktif yang mengatur urusan-urusan bumi. Tidak aneh jika urusanurusan langit lebih teratur dan kokoh, karena akal-akal yang tidak ada pada benda dan jiwa-jiwa falakiahlah yang mengawasinya. Alam langit memiliki kesucian yang sudah dikenal oleh orang Yunani sejak dulu, dan dikuatkan oleh agama-agama samawi. Dari akal kesepuluh keluar (beremansipasi) alam yang temporal, karena daripadanya unsur-unsur pertama bersandar, yang melahirkan tambang, tumbuhan dan hewan, kemudian manusia sebagai entitas yang paling mulia.

Akal manusia merupakan salah satu potensi jiwa, dan disebut rational soul. Ia ada dua macam:

1. Praktis bertugas mengendalikan badan dan mengatur tingkah laku.

2. Teoritis khusus berkenaan dengan persepsi dan epistemologi, karena akal praktis inilah yang menerima persepsi-persepsi inderawi dan meringkas pengertianpengertian universal daripadanya dengan bantuan akal aktif, yang terhadap jiwa kita bagaikan matahari terhadap pandangan mata kita. Akal manusia bisa meningkat ke

${ }^{5}$ Andi Hakim Nasoetion, Pengantar ke Filsafat Sains, (Jakarta: Litera Antar Nusa, 2003), p. 51. 
alam atas hingga berhubungan langsung dengan akal-akal yang tidak ada pada benda, sehingga ia bisa mengetahui obyek-obyek pemikiran sekaligus. Di samping itu, juga bisa menukik ke alam kesucian dan kenikmatan tinggi-dan inilah kebahagiaan tertinggi. 6

\section{B. Rasio dan Rasa}

Ilmu Barat atau modern hanya mengakui rasio (akal) yang menghasilkan ilmu nomotetikal. Ilmu normatif tidak boleh mencampuri ilmu nomotetikal. Inilah yang oleh Weber disebut "etis netral". Bila keduanya itu bercampur (confused) kesimpulan yang ditarik akan kabur. Ilmu nomotetikal adalah ilmu yang "lugas-formal". Berbeda dengan Weber, pandangan hidup kita menghendaki keseimbangan antara rasio dan rasa. Ilmu rasio (akal) atau nomotetikal berlandaskan hukum-hukum sebab akibat, yaitu: segala sesuatu memerlukan penyebab agar maujud; "ada asap pasti ada apinya". Sebab akibat ini disebut kausalitas. Kausalitas adalah keperilakuan jagat raya dan juga keperilakuan manusia. Kita akan sulit hidup, bila hukum sebab akibat itu tidak ada di alam empirik. Kausalitas disebut juga Sunnatullah, ketetapan tuhan sebagaimana telah dijelmakan di jagat raya ini. Sunnatullah ini merupakan ketetapan yang abadi, yang merupakan pegangan bagi manusia dalam melaksanakan perintah-perintah Allah.

Pada prinsipnya kausalitas tergantung pada: pertama, pembuktian realitas objektif persepsi inderawi. Kedua, semua teori dan hukum ilmiah yang bersandarkan pada eksperimen. Ketiga, kemungkinan penyimpulan dan kesimpulan-kesimpulannya dalam bidang filsafat maupun ilmu. Kalau saja tidak karena prinsip dan hukum-hukum kausalitas, tentu tidak mungkin memaparkan objektivitas persepsi inderawi, tidak pula teori ilmu dan hukum ilmu apapun, dan tentu tidak mungkin menyimpulkan dalam bidang pengetahuan manusia apapun berdasarkan bukti apapun.

Persepsi inderawi tidak lebih daripada bentuk konsepsi. Ia adalah hadirnya bentuk sesuatu yang terinderai dalam fakultas-fakultas inderawi, dan tidak memiliki karakter suatu pengungkapan sejati tentang realitas luar. Karena itu, dalam kasus penyakit tertentu manusia dapat memiliki persepsi inderawi tentang hal-hal tertentu tanpa menetapkan adanya hal-hal itu. Jadi, persepsi inderawi bukanlah dasar yang memadai untuk menetapkan, menilai atau mengetahui realitas objektif. Dengan demikian

${ }^{6}$ Ibrahim Madkour, Aliran dan Teori Filsafat Islam, (Jakarta: Bumi Aksara, 2005), p. 247. 
permasalahan yang kita hadapi adalah bahwa kalau persepsi inderawi itu sendiri bukanlah bukti bagi adanya sesuatu yang terinderai yang ada di luar batas-batas kesadaran dan pengetahuan, maka bagaimana kita dapat menetapkan adanya realitas objektif? Jawabannya ada pada telaah kami tentang teori pengetahuan. Menetapkan adanya suatu realitas objektif alam adalah penetapan yang niscaya lagi primer karena itu tidak membutuhkan bukti. Tetapi penetapan niscaya itu menunjukkan hanya adanya suatu realitas-luar alam secara global. Sedangkan realitas objektif setiap persepsi inderawi tidak diketahui secara niscaya. Karena itu dibutuhkan bukti untuk membuktikan objektivitas setiap persepsi inderawi tertentu. Bukti itu adalah prinsip dan hukum-hukum kausalitas.

Terjadinya (dalam indera) bentuk sesuatu tertentu di dalam kondisi dan keadaan tertentu mengungkapkan, sesuai dengan prinsip ini, adanya sebab luar sesuatu itu. Kalau tidak karena prinsip tersebut tentu persepsi inderawi atau adanya sesuatu di dalam indera tidak dapat mengungkapkan adanya sesuatu itu di tempat lain. Karena itulah, dalam keadaan sakit tertentu manusia dapat menginderai hal-hal tertentu atau membayangkan bahwa ia melihat hal-hal itu tanpa mengetahui realitas objektif hal-hal tersebut. Ini karena prinsip kausalitas tidak membuktikan adanya realitas tersebut, selama dimungkinkan untuk menerangkan persepsi inderawi melalui keadaan sakit tertentu itu. Tetapi ia membuktikan realitas objektif persepsi inderawi jika tidak ada keterangan tentangnya berdasarkan prinsip kausalitas kecuali dengan realitas objektif yang melahirkan persepsi inderawi itu.

Berdasarkan uraian tersebut dapat saya simpulkan tiga proposisi berikut:

1. Persepsi inderawi itu sendiri tidak mengungkapkan adanya realitas objektif. Karena ia adalah konsepsi dan adalah bukan tugas konsepsi (tak soal dengan jenisnya) untuk memberikan pengungkapan yang benar.

2. Mengetahui adanya realitas alam secara secara global adalah suatu ketetapan (judgement) yang niscaya lagi primer yang tidak membutuhkan bukti; yakni, tidak perlu tahu terlebih dahulu. Inilah yang memisahkan idealisme dari realisme.

3. Mengetahui suatu realitas objektif persepsi inderawi ini atau itu dapat terjadi dengan berdasarkan prinsip kausalitas.

Teori-teori ilmiah dalam berbagai lapangan eksperimen dan observasional secara umum bergantung secara mendasar pada prinsip dan hukum-hukum kausalitas. Jika 
kausalitas dan sistem tertentunya terhapus dari alam semesta, maka penciptaan teori ilmiah dalam lapangan apapun akan menjadi sulit sekali. Sedikitnya ada tiga hal yang harus dipaparkan sejumlah hukum kausal dari himpunan (hukum) filosofis yang menjadi sandaran ilmu pengetahuan, hukum-hukum itu adalah sebagai berikut:

1. Prinsip kausalitas yang menyatakan bahwa setiap peristiwa mempunyai sebab.

2. Hukum keniscayaan yang menyatakan bahwa setiap sebab niscaya melahirkan akibat alaminya, dan bahwa tidak mungkin akibat terpisah dari sebabnya.

3. Hukum keselarasan antara sebab dan akibat yang menyatakan bahwa setiap himpunan alam yang secara esensial selaras mesti pula selaras dengan sebab dan akibatnya. ${ }^{7}$

Berdasarkan hukum keniscayaan, kita dapati bahwa keterbagian tersebut, ketika kondisi-kondisi niscayanya telah terpenuhi niscaya melahirkan radiasi tertentu. Adanya kondisi-kondisi ini dan pelahiran radiasi ini tidak mungkin dapat dipisahkan. Adalah jelas bahwa dua hukum terakhir tersebut-hukum keniscayaan dan hukum keselarasanmuncul dari prinsip kausalitas. Dengan demikian kita tahu bahwa membuat teori umum, tanpa berangkat dari prinsip kausalitas, tidaklah mungkin.

Jadi, prinsip kausalitas adalah asas pertama semua ilmu pengetahuan dan teoriteori eksperimental. Kesimpulannya teori-teori eksprimental tidak mendapatkan sifat ilmiah, selama tidak digeneralisasikan untuk mencakup bidang-bidang di luar batasbatas eksperimen tertentu dan dijadikan sebagai kebenaran umum. Tidak mungkin dijadikan demikian kecuali berdasarkan prinsip dan hukum-hukum kausalitas. Karena itu, ilmu-ilmu pengetahuan secara umum harus menganggap prinsip kausalitas dan kedua hukumnya yang berkaitan erat yaitu hukum keniscayaan dan hukum keselarasan, sebagai kebenaran-kebenaran yang secara mendasar diterima, dan menerimanya sebelum semua teori dan hukum eksperimental ilmu-ilmu pengetahuan.

Sedangkan pada Kausalitas dan Inferensi dikatakan bahwa: prinsip kausalitas adalah dasar tumpuan segala usaha pemaparan dalam segala bidang pemikiran manusia. Ini karena pemaparan bukti tentang sesuatu berarti bahwa jika bukti itu benar, maka adalah sebab bagi mengetahui sesuatu itulah yang merupakan objek pemaparan. Ketika kita membuktikan suatu kebenaran tertentu dengan eksperimen ilmiah atau dengan

\footnotetext{
${ }^{7}$ Baqir, Falsafatuna, p. 208.
} 
suatu hukum filsafat atau dengan persepsi inderawi sederhana, sebenarnya kita hanya berusaha agar bukti tersebut menjadi sebab diketahuinya kebenaran itu. Kalau tidak karena prinsip kausalitas dan (hukum) keniscayaan, tentu kita tidak akan dapat berbuat hal-hal itu. Karena, kalau kita membuang hukum-hukum kausalitas dan tidak mempercayai keniscayaan adanya sebab-sebab tertentu bagi setiap kejadian, tentu tidak akan ada hubungan antara bukti yang kita sadari dan kebenaran yang kita usahakan mendapatkannya dengan bukti ini. Tetapi kemungkinan bahwa bukti itu benar tanpa memadu ke hasil yang dikehendaki, karena hubungan kausal antara bukti dan hasil, antara sebab dan akibat, itu telah terputus.

Demikianlah, menjadi jelas bahwa setiap upaya pemaparan bergantung pada diterimanya prinsip kausalitas. Kalau tidak tentu upaya itu hanya sia-sia. Bahkan pemaparan untuk menolak prinsip kausalitas, yang diusahakan oleh sebagian filosof dan ilmuwan, juga berdasarkan prinsip kausalitas. Karena, mereka yang mencoba mengingkari prinsip tersebut dengan berdasarkan pada suatu hujah tertentu tidaklah melakukan usaha itu, kalau mereka tidak mempercayai bahwa hujah yang mereka sandari itu adalah sebab yang memadai untuk mengetahui kepalsuan prinsip kausalitas. Tetapi hal itu sendiri adalah suatu penerapan literal (harfiah) prinsip itu. ${ }^{8}$

Berdasarkan dari berbagai uraian di atas, dapat saya buat kesimpulan sebagai berikut:

1. Prinsip kausalitas tidak mungkin dibuktikan dan dipaparkan secara empirik. Karena, indera tidak mendapatkan sifat objektif, kecuali jika berdasarkan prinsip tersebut. Kita membuktikan realitas objektif persepsi inderawi kita berdasarkan prinsip kausalitas. Jadi, tidaklah mungkin bahwa untuk pemaparannya prinsip itu bergantung pada indera. Tetapi adalah prinsip rasional indera-indera eksternallah yang orang terima secara mandiri.

2. Prinsip kausalitas bukanlah teori ilmiah eksperimental. Tetapi, ia adalah hukum filsafat rasional di atas eksperimen. Karena, semua teori ilmiah bergantung padanya. Ini tampak dengan sangat jelas setelah kita mengetahui bahwa setiap deduksi (penyimpulan) ilmiah yang berdiri di atas eksperimen menghadapi persoalan keumuman (generalitas) dan kemencakupan (komprehensif), yaitu bahwa eksperimen yang menjadi dasar penyimpulan ilmiah itu terbatas. Jadi, prinsip

${ }^{8}$ Ibid, pp. 209-210. 
kausalitas haruslah berada di atas eksperimen dan kaidah dasar penyimpulanpenyimpulan eksperimental secara umum.

3. Prinsip kausalitas tidak mungkin ditolak dengan hujah apapun. Karena, setiap usaha seperti ini justru menyebabkan pengakuan terhadap prinsip itu sendiri. Jadi, prinsip ini adalah tetap kukuh sebelum dibuktikan manusia.

Ikhtisar kesimpulan-kesimpulan itu adalah: Prinsip kausalitas bukanlah prinsip eksperimental, tapi adalah prinsip yang niscaya lagi rasional. Berdasarkan hal tersebut, dapatlah kita membuat perbedaan antara mekanika dan dinamika, dan antara prinsip kausalitas dan prinsip kebebasan (indeterminasi). Penafsiran mekanik terhadap kausalitas itu berdasarkan anggapan bahwa kausalitas adalah prinsip eksperimental.

Pendapat kita tentang kausalitas, yang menyatakan bahwa ia adalah prinsip rasional di atas eksperimen, maka situasinya menjadi berbeda sekali berkenaan dengan beberapa segi:

1. Kausalitas tidak terbatas pada fenomena-fenomena alam yang tampak di dalam eksperimen, tetapi ia adalah hukum umum keberadaan pada umumnya, yang mencakup fenomena-fenomena alam, yaitu materi itu sendiri serta apa yang ada di balik materi, yaitu macam-macam keberadaan.

2. Sebab, yang keberadaannya dikukuhkan oleh prinsip kausalitas, tidaklah perlu dieksperimen, atau merupakan sesuatu material.

3. Tidak adanya pengungkapan eksperimen mengenai sebab tertentu bagi perkembangan tertentu atau fenomena tertentu, tidak berarti gagalnya prinsip kausalitas. ${ }^{9}$

Berdasarkan uraian di atas, dapatlah kita membedakan adanya perbedaan mendasar antara gagasan kita tentang prinsip kausalitas dan gagasan mekanik prinsip ini, dan juga melihat bahwa keragu-raguan yang timbul sekitar prinsip kausalitas tidak lain adalah hasil dari penafsiran tentangnya yang sesuai dengan konsep mekanik yang tidak sempurna.

Hukum sebab akibat yang berlaku bagi alam dan manusia tidaklah terlalu sama. Tuhan menciptakan jagat raya sebagai suatu "order" (kosmos) dengan ketundukan seratus persen terhadap Sunnatullah, sebagaimana terdapat dalam Al-Qur'an, surat Al-

${ }^{9}$ Baqir, Falsafatuna, pp. 211-2. 
Fushshilat: 11, yang artinya: “Kemudian dia menuju langit dan langit itu masih merupakan asap, lalu dia berkata kepadanya dan kepada bumi: "Datanglah kamu keduanya menurut perintah-Ku dengan sukahati atau terpaksa," keduanya menjawab: kami datang dengan sukahati" ${ }^{10}$

Newton mencoba untuk memahami "order", namun order Newtonian itu diruntuhkan oleh para ilmuwan pasca-Newtonian. Mereka berhasil meruntuhkannya, tapi apa gantinya? belum ada yang memuaskan. Tarnas menyatakan bahwa gantinya adalah "...reality may not be structured in any way the human mind can objectively discern", dan selain itu...and the post-Newtonian world order....was scarcely an order at all. Bagaimana kiranya Sunnatullah untuk manusia, seperti dalam Al-Qur'an, surat Al-Kahfi: 29, yang artinya: "Dan katakanlah: "Kebenaran itu datangnya dari Tuhanmu: maka barangsiapa yang ingin (beriman) hendaklah ia beriman, dan barang siapa yang ingin (kafir) biarlah ia kafir".11

Teori Structural-Functional dari Parsons, Merton, dan sebagainya, mereka meletakkan kekuatan pada struktur dan fungsi, maka manusia itu hanyalah dipandang sebagai "sekrup" saja. Ia tidak ubahnya seperti batu yang didorong kekiri atau kekanan, dan tidak berdaya apa-apa. Namun sebaliknya teori Behaviorism (G. Herbert Mead dan sebagainya) sangat memandang bahwa orang melihat sekelilingnya dengan "meaning dan attitude" menurut pandangannya, maka ia mampu membuat keputusan (choice) berdasarkan pandangannya itu. Maka teori Mead lebih cocok dengan Al-Qur'an daripada teori Parsons/ Merton.

Al-Ghazali mengakui adanya regularitas, karena regularitas adalah kebiasaan (adah) Tuhan. Tapi yang dipermasalahkannya ada kekuatan yang menimbulkan akibat dari sebab itu. Ia memandang bahwa kekuatan itu adanya Tuhan sehingga akibat yang akan terjadi atau tidak tergantung pada Tuhan apakah kekuatan itu akan diberikannya atau tidak. Sebab bila kekuatan itu ada pada benda-benda, maka menurut Al-Ghazali Tuhan bertindak "self-conrtadictory". Maka kekuatan itu tidak terdapat pada bendabenda. Pandangan yang sekarang berlaku, seperti pandangan Kant yang mengagumi deterministik Newton, kekuatan-kekuatan itu telah di delegation of authoritykan. Namun

10 Departemen Agama Republik Indonesia, Al-Qur'an dan Terjemahannya, (Semarang: CV. Toha Purta, 1999), p. 774.

11 Ibid., p. 440, 
menurut Tarnas, certainties kini telah gugur, dan orang cenderung untuk stokastik, demikian juga penemuan Heisenberg tentang "uncertainty principle".

Immanuel Kant mengatakan "dengan bagaimanapun juga tiada akal manusia (juga tiada akal yang terbatas, yang menilik sifatnya sama dengan akal kita, tetapi menilik tingkatnya betapapun juga jauh melebihinya) dapat berharap akan memahami penghasilan rumput yang kecil sekalipun dengan sebab-sebab yang sifatnya mekhanis belaka." Sedangkan DR. Frans Dahler mengatakan "menurut Marxisme, agama akan lenyap, karena ilmu pengetahuan makin lama makin mampu mengartikan hidup dan membebaskan manusia dari penderitaan. Namun sesungguhnya ilmu tetap tak dapat menjawab beberapa pertanyaan yang mendasar dan terpendam dalam sanubari manusia, misalnya tentang arti kematian, sukses gagalnya cinta, maka sengsara yang tak dapat dihindarkan oleh ilmu yang paling maju sekalipun. Dan lebih daripada itu, ilmu tak dapat memenuhi kerinduan, kehausan manusia akan cinta mutlak dan abadi." Lain lagi dengan Jean Paul sartre pernah mengemukakan sebagai berikut: "Apakah Pengetahuan? Ilmu pengetahuan bukanlah sesuatu hal yang sudah selesai terpikirkan, sesuatu hal yang tidak pernah mutlak, sebab selalu akan disisihkan oleh hasil-hasil penelitian dan percobaan-percobaan baru yang dilakukan dengan metode-metode baru atau penemuan baru ini akan disisihkan pula oleh ahli-ahli lainnya kadang-kadang kembali mundur, tetapi seringnya lebih maju. ${ }^{12}$

Berdasarkan dari beberapa uraian di atas dapat saya ditarik kesimpulan bahwa:

1. Tidak semua permasalahan yang dipersoalkan manusia dalam hidup dan kehidupannya dapat dijawab dengan tuntas oleh ilmu pengetahuan itu.

2. Nilai kebenaran ilmu pengetahuan itu bersifat positif dalam arti sampai saat sekarang ini dan juga bersifat relatif atau nisbi dalam arti tidaklah mutlak kebenarannya.

3. Batas dan relativitas ilmu pengetahuan bermuara pada filsafat, dalam arti bahwa semua permasalahan yang berada di luar atau di atas jangkauan dari ilmu pengetahuan itu diserahkanlah kepada filsafat untuk menjawabnya.

\section{Dunia Rasa}

12 Burhanuddin Salam, Pengantar Filsafat, (Bandung: Multi Karya Ilmu, 2009), p. 24. 
Dalam tubuh manusia terdapat sebuah alat yang sangat vital fungsinya, yang terdiri dari segumpalan darah yang suci, dan peka terhadap permasalahan yang timbul dan terjadi di sekeliling kita. Dia terletak paling dalam dari tubuh manusia, dia dapat mengatur perasaan seseorang, ketika dihadapkan pada rasa senang, gembira, sedih, duka, gelisah dan sebagainya. Dia adalah hati (kalbu), yang punya rasa dan makna sangat dalam.

Dunia rasa (kalbu) menurut Herman Soewardi dapat dikelompokkan ke dalam tiga tingkatan yaitu: biasa, hati nurani (conscience), dan rasa yang disucikan. Rasa peringkat biasa banyak membantu kita dalam tugas sehari-hari seperti pengemudi, pemain musik, dokter, manajer, negarawan, dan sebagainya, tidak akan mampu melakukan tugasnya bila tidak dibantu rasa. Semuanya menggunakan judgement baik tanpa maupun dengan bantuan alat. Peringkat hati nurani atau conscience digunakan oleh ahli-ahli hukum, misalnya seorang hakim. Dalam menetapkan suatu vonis, data-data harus ditunjang dengan hati nurani dalam menetapkan apakah seseoarang itu salah atau benar, berhak atau tidak berhak. Adapun peringkat ketiga, ialah rasa yang disucikan, terdapat pada para sufi atau tasawuuf amali, dalam rangka mendekatkan diri kepada Tuhan (Takarrub). Dunia rasa itu dapat dibagikan lagi ke dalam: (1) idealisme irrasional; (2) etika dan hukum; (3) estetika; (4) exrta sensory perception; dan (5) rasa yang disucikan. Nomor (1), (2), dan (3) memperoleh sensasi melalui penginderaan, sedangkan nomor (4) dan (5) tidak melalui penginderaan, atau disebut supra-indrawi. ${ }^{13}$

Allah SWT adalah satu-satunya Dzat yang sedang mengurus tubuh kita. Kalaupun dinyatakan bahwa Allah itu lebih dekat dengan urat leher kita, itu pasti karena yang menciptakan dan mengurus urat leher kita juga adalah Allah. Oleh sebab itu, tidak ada yang luput dari pandangan Allah, mutlak pasti segala-galanya disaksikan dan diketahui dengan jelas oleh-Nya. Tidak ada yang tersembunyi bagi-Nya, karena itu keberuntungan yang besar di dunia ini bukanlah orang yang diberi dunia (harta, gelar, pangkat, jabatan, dan sebagainya), melainkan orang yang dibukakan matahatinya, sehingga selalu merasakan kedekatan, keagungan, kehebatan, dan keperkasaan Allah. Betapa tidak, siapa saja yang sudah sampai ke tingkat yakin kepada Allah, maka tidak ada lagi yang membuatnya risau di dunia ini karena dia tahu persis bahwa pertolongan Allah itu sangat

${ }^{13}$ Herman Soewardi, Nalar, Kontemplasi dan Realita, (Bandung: Unpad, 2005), p. 76. 
dekat, lebih cepat datangnya daripada kilat yang menyambar. Sementara itu, tidak ada yang perlu diragukan sama sekali bahwa Allah itu tidak pernah dusta dengan janji-Nya. Janji Allah itu pasti, tidak ada keraguan sama sekali. Pertolongan Allah itu pasti datang. Kesulitan pasti dimudahkan dengan cara yang paling bijaksana oleh Allah Azza wa Jalla.

Tidak ada persoalan dengan dunia ini. Kesulitan dan persoalan pasti sudah ada menyertai hidup kita. Akan tetapi, semua itu hanyalah alat dari Allah supaya kita makin akrab dengan Dzat Yang Maha Menciptakan dan Maha Mengurus segala-galanya. Tidak ada yang menjadi persoalan di dunia ini, kecuali hubungan kita dengan Allah. Wa man yattaqilaah, yaj'allahuu makhraja (Q.S. Ath-Thalaaq. 65: 2). Kalau engkau terus mendekat dan taat kepada Allah, maka Dia pasti memberikan jalan keluar atas segala persoalan yang menimpa. Ini berarti, persoalan itu pasti ada. Dan jalan keluar itu hanya akan terbentang, sehingga aneka persoalan akan selesai dengan bijak dan indah kalau kita mendekat kepada Allah. Wa yarzuqhuu min haitsu laa yahtashib. (Q. S. Ath Thalaaq. 65: 3). ${ }^{14}$ Bahwa Allah akan mendatangkan pertolongan dari tempat yang tidak di sangkasangka. Artinya, kita akan masuk ke dalam suatu situasi yang kadang-kadang sulit sekali, sehingga kita merasakan dunia ini begitu gelap seperti masuk ke dalam peti besi yang seluruhnya dikunci mati, dilas, sampai tidak ada lubang sama sekali. Namun, bagi orang yang mengenal Allah dengan baik, semakin pelik persoalan, membuatnya semakin yakin, bahwa pertolongan Allah pasti datang dari tempat yang tidak disangka-sangka.

Tidak ada celah untuk kita menjadi kecewa dalam menghadapi hidup ini. Kecewa hanyalah buah dari salah perhitungan dan salah sikap terhadap ketentuan dari Allah Yang Maha Pengasih dan Maha Penyayang. Kendatipun demikian, bagi sebagian orang yang belum sampai ke tingkat yakin akan kemahadekatan pertolongan Allah. Segala persoalan dan kesulitan yang datang menimpa sekecil apapun-justeru seringkali membuahkan rasa cemas dan gundah gelisah di dalam hatinya. Akibatnya, dari hari ke hari hidupnya dipenuhi aneka keluh kesah, amarah dan tingkah serba salah. Hidup ini sungguh terasa sumpek, mumet, menyesakkan dada, serta membuat kepala pening. Segala yang terhidang di depan mata, terdengar di telinga, atau yang teraba oleh tangan terasa semakin membebani hati dan pikirannya. Tidak jarang kegelisahan hati ini menjadi jalan yang terbentang bagi terjerumusnya ke jurang maksiat. Alih-alih agar diri terhindar atau sekurang-kurangnya dapat melupakan segala malapetaka persoalan yang

14 Ibid., pp. 945-6. 
menghimpit. Justru malah menambah berat beban persoalan tersebut. Ini jelas salah sikap.

Padahal perasaan cemas, gelisah, keluh kesah, dan amarah jelas tidak akan mengubah apapun, selain hanya membuat dirinya semakin tersesat dalam rimba kesulitan dan semakin merasa jauh dari pertolongan Allah. Bagaimana cara mengatasi dan merendam perasaan-perasaan tersebut? Kalau Anda merasakan gelisah hati, maka cobalah wiridkan secara berulang-ulang untaian Asmaul Husna berikut ini: Ya Haliim, ya 'Aliim, ya 'Aliyyu, ya 'Azhiim ..... terus, berulang-ulang seraya diresapi dan diakui dengan sepenuh hati betapa Allah itu memiliki nama-nama yang Agung, yang dengan mengingat dan mendzikirkannya kedekatannya dengan Allah dan dengan Sayang-Nya Dia akan menurunkan ketenangan ke dalam kalbu kita dan mengeluarkan kita dari segala persoalan yang tengah melanda.

\section{Idealisme Irrasional}

Paham ini mulai berkembang pada abad ke-19, dan disebut idealisme negatif atau idealisme irrasional. Idealisme ini tidak memandang dunia melalui kemampuan rasional, akan tetapi melalui keinginan atau will, sebagai landasan untuk menerangkan seperti apa wujud dunia ini. Tokohnya adalah Schopenhauer yang mengemukakan bahwa sains hanya mampu menerangkan secara materialistis segala phenomena. Ia percaya bahwa dunia sebagai idea hanya merupakan manisfestasi superfisial, demikian pula eksistensi atau keberadaannya yang superfisial. Maka haruslah ada benda itu sendiri (the thing in itself) yang merupakan substratum dari yang bersifat superfisial itu. Substratum ini tak lain adalah keinginan atau will.

Pelanjut Schopenhauer adalah Nietzsche. Ia juga memandang will sebagai fakta dasar dari manusia. Realisasi daripadanya ada dua macam: will manusia yang diekspresikan secara kalem, dan yang diekspresikan secara passionate. Ia mengutuk semua agama, khususnya agama Nasrani. Dikatakan bahwa Tuhan telah mati.

Berbicara tentang idealisme atau keinginan kita terhadap sesuatu hal memang sangat penting, tetapi hal ini harus dibarengi dengan kemampuan yang kita miliki, misalnya kita ingin berbuat jauh lebih ke depan, tetapi kita punya pengalaman, ilmu pengetahuan yang tentang hal itu. Maka di sini letak akal sehat kita yang harus dipergunakan dan didukung dengan hati suci dan ikhlas, agar segala sesuatu yang ingin 
kita kerjakan dapat bermanfaat dengan baik dan tidak bertentangan dengan nilai-nilai sosial kemasyarakatan, nilai-nilai agama, moral bangsa dan negara. Untuk itu kita selaku mahluk ciptaan Allah SWT yang paling sempurna dan mulia, kita diberi akal sehat dan hati yang bersih. Pergunakan akal kita sesuai dengan kemampuannya, agar segala keinginan atau idealisme dapat tercapai bukan hanya idealisme irrasional belaka, punya cita-cita tetapi tidak barengi dengan kemampuan yang cukup, maka idealisme kita hanya isapan jempol biasa bahkan hanya menjadi angan-angan bekala saja.

Ada dua teori untuk mengetahui hakikat kebenaran itu. Pertama realisme, yang mempunyai pandangan realistis terhadap alam. Pengetahuan menurut realisme adalah gambaran atau kopi yang sebenarnya dari apa yang ada dalam alam nyata (dari fakta atau hakikat). Pengetahuan atau gambaran yang ada dalam akal adalah kopi dari yang asli yang di luar akal. Hal ini tidak ubahnya seperti gambaran yang terdapat dalam foto. Dengan demikian, realisme berpendapat bahwa pengetahuan adalah benar dan tepat bila sesuai dengan kenyataan. Ajaran realisme percaya bahwa dengan sesuatu atau lain cara, ada hal-hal yang hanya terdapat di dalam dan tentang dirinya sendiri, serta yang hakikatnya tidak terpengaruh oleh seseorang.

Para penganut realisme mengakui bahwa seseorang bisa salah lihat pada bendabenda atau dia melihat terpengaruh oleh keadaan sekelilingnya. Namun, mereka paham ada benda yang dianggap mempunyai wujud tersendiri, ada benda yang tetap kendati tidak diamati. Menurut Prof. Dr. Rasjidi, penganut agama perlu sekali mempelajari realisme dengan alasan:

1. Dengan menjelaskan kesulitan-kesulitan yang terdapat dalam pikiran. Kesulitan pikiran tersebut adalah pendapat yang mengatakan bahwa tiap-tiap kejadian dapa diketahui hanya dari segi subjektif. Menurut Rasjidi, pernyataan itu tidak benar sebab adanya faktor subjektif bukan berarti menolak faktor objektif. Kalau seseorang melihat sebatang pohon, tentu pohon itu memang pohon itu dilihat oleh si subjek. Namun, hal ini tidak berarti meniadakan pohon yang mempunyai wujud tersendiri. Begitu juga ketika orang berdoa kepada Tuhan, bukan berarti Tuhan itu hanya terdapat dalam pikiran, tetapi Tuhan mempunyai wujud tersendiri.

2. Dengan jalan memberi pertimbangan-pertimbangan yang positif, menurut Rasjidi, umumnya orang beranggapan bahwa tiap-tiap benda mempunyai satu sebab. Contohnya, apa yang menyebabkan Ahmad sakit. Biasanya kita puas ketika dijawab karena kuman. Sebenarnya, sebab sakit itu banyak sekali karena ada orang yang bersarang kuman dalam tubuhnya, tetapi dia tidak sakit. Dengan demikian, penyakit si Ahmad itu mungkin disebabkan keadaan badannya, iklim, dan sebagainya. Prinsip 
semacam ini, menurut Rasjidi, bisa digunakan untuk mempelajari agama karena adanya perasaan yang subjektif tidak berarti adanya keadaan yang objektif. ${ }^{15}$

Teori kedua tentang hakikat pengetahuan adalah idealisme. Ajaran idealisme menandaskan bahwa untuk mendapatkan pengetahuan yang benar-benar sesuai dengan kenyataan adalah mustahil. Pengetahuan adalah proses-proses mental atau proses psikologis yang bersifat subjektif. Oleh karena itu, pengetahuan bagi seorang idealis hanya merupakan gambaran subjektif dan bukan gambaran objektif tentang realitas. Subjektif dipandang sebagai suatu yang mengetahui, yaitu dari orang yang membuat gambaran tersebut. Karena itu, pengetahuan menurut teori ini, tidak menggambarkan hakikat kebenaran. Yang diberikan pengetahuan hanyalah gambaran menurut pendapat atau penglihatan orang yang mengetahui (subjek).

Kalau realisme mempertajam perbedaan antara yang mengetahui dan yang diketahui, maka idealisme adalah sebaliknya. Bagi idealisme, dunia dan bagianbagiannya harus dipandang sebagai hal-hal yang mempunyai hubungan, seperti organ tubuh dengan bagian-bagiannya. H.M. Rasjidi menganggap bahwa subjektivitas idealisme ini berbahaya bagi agama. Subjektivisme berarti anggapan bahwa kebenaran sesuatu hal ditentukan oleh si subjek. Karena itu, menurut Rasjidi bisa saja dikatakan bahwa Tuhan itu mungkin ada untuk si A, tetapi si B tidak mengakuinya.

Rasjidi tampaknya lebih cenderung pada realisme ketimbang idealisme. Realisme, menurutnya adalah kenyakinan bahwa benda itu ada tersendiri dan terpisah daripada pikiran orang yang mengetahuinya. Benda itu bisa merupakan benda fisik, seperti pohon dan batu, tetapi juga mungkin merupakan hal yang bersifat ide universal.

Sebenarnya, realisme dan idealisme memiliki kelemahan-kelemahan tertentu. Realisme ekstrim bisa sampai pada monisme materialistis atau dualisme. Seorang pengikut materialisme mengatakan jika demikian halnya, sudah barang tentu dapat juga dikatakan bahwa jiwa adalah materi dan materi adalah jiwa, bahkan jiwa dan materi sepenuhnya sama. Lebih lanjut, realisme tidak terlalu mementingkan subjek sebagai penilai, tetapi hanya memfokuskan pada objek yang dinilai. Padahal, subjek yang menilai memiliki peran penting dalam menghubungkan antara objek dengan ungkapan tentang objek tersebut.

${ }^{15}$ Amsal Bakhtiar, Filsafat Agama, (Jakarta: Logos Wacana Ilmu, 2008), p. 37. 
Idealisme subjektif juga akan menimbulkan kebenaran yang relatif karena setiap individu berhak untuk menolak kebenaran yang datang dari luar dirinya. Akibatnya, kebenaran yang bersifat universal tidak diakui. Kalau demikian jadinya, maka aturanaturan agama dan kemasyarakatan hanya bisa benar untuk kelompok tertentu dan tidak berlaku bagi kelompok yang lain. Lagi pula, idealisme terlalu mengutamakan subjek sebagai si penilai, dengan merendahkan objek yang dinilai. Sebab, subjek yang menilai kadangkala berada pada keadaan yang berubah-ubah, seperti sedang marah dan gembira. ${ }^{16}$

\section{E. Etika Dan Hukum}

Etika juga berarti akhlaq. Perkataan ini berasal dari bahasa Yunani "ethos" yang berarti adat kebiasaan. Filsafat etika merupakan bagian daripadanya, di mana para ahli memberikan ta'rif dalam redaksi kalimat yang berbeda-beda, antara lain:

1. Etika ialah ilmu tentang tingkah laku manusia prinsip-prinsip yang disistimatisir tentang tindakan moral yang betul (webster's Dict.).

2. Bagian filsafat yang memperkembangkan teori tentang tindakan, hujah-hujahnya dan tujuan yang diarahkan kepada makna tindakan (Ensiklopedi Winkler Prins).

3. Ilmu tentang filsafat moral, tidak mengenal fakta, tetapi tentang nilai-nilai, tidak mengenai sifat tindakan manusia, tetapi tentang idenya, karena itu bukan ilmu yang positif tetapi ilmu yang normatif (New American Encyl).

4. Ilmu tentang moral/prinsip-prinsip kaidah-kaidah moral tentang tindakan dan kelakuan (A.S. Hornby Dict. $)^{17}$

Sesuai dengan hal-hal tersebut di atas, maka pengertian etika menurut filsafat dapat dirumuskan sebagai berikut: Etika ialah ilmu yang menyelidiki mana yang baik dan mana yang buruk dengan memperhatikan amal perbuatan manusia sejauh yang dapat diketahui oleh akal pikiran.

Ada orang yang berpendapat bahwa etika sama dengan akhlak. Persamaan itu memang ada, karena keduanya membahas masalah baik buruknya tingkah laku manusia. Tujuan etika dalam pandangan filsafat ialah mendapatkan ide yang sama bagi seluruh manusia di setiap waktu dan tempat tentang ukuran tingkah laku yang baik dan buruk sejauh yang dapat diketahui oleh akal pikiran manusia. Akan tetapi dalam usaha mencapai tujuan itu, etika mengalami kesulitan, karena pandangan masing-masing

16 Ibid., p. 38.

17 Hamzah Ya'qub, Etika Islam. Pembinaan Akhlaqulkarimah (Suatu Pengantar), (Bandung: Diponegoro, 2006), p. 13. 
golongan di dunia ini tentang baik dan buruk mempunyai ukuran (kriteria) yang berlainan. Sebagai cabang dari filsafat, maka etika bertitik tolak dari akal pikiran, tidak dari agama. Di sinilah letak perbedaannya dengan akhlaq dalam pandangan Islam. Dalam pandangan Islam, ilmu akhlaq ialah suatu ilmu pengetahuan yang mengajarkan mana yang baik dan mana yang buruk berdasarkan ajaran Allah dan Rasul-Nya. Ajaran Etika Islam sesuai dengan fitrah dan akal pikiran yang lurus.

Untuk menghilangkan kesamaran tersebut, maka kiranya perlulah diketahui karakteristik Etika Islam yang membedakannya dengan Etika Filsafat, yaitu sebagai berikut:

1. Etika Islam mengajarkan dan menuntun manusia kepada tingkah laku yang baik dan menjauhkan diri dari tingkah laku yang buruk.

2. Etika Islam menetapkan bahwa yang menjadi sumber moral, ukuran baik buruknya perbuatan, didasarkan kepada ajaran Allah SWT (Al-Qur'an dan RasulNya/ Sunnah).

3. Etika Islam bersifat universal dan komprehensif, dapat diterima oleh seluruh ummat manusia di segala waktu dan tempat.

4. Dengan ajaran-ajarannya yang praktis dan tepat, cocok dengan fithrah (naluri) dan akal pikiran manusia (manusiawi), maka Etika Islam dapat dijadikan pedoman oleh seluruh manusia.

5. Etika Islam mengatur dan mengarahkan fithrah manusia ke jenjang akhlaq yang luhur dan meluruskan perbuatan manusia di bawah pancaran sinar petunjuk Allah SWT, menuju keridlaan-Nya. Dengan melaksanakan Etika Islam niscaya akan selamatlah manusia dari pikiran-pikiran dan perbuatan-perbuatan yang keliru dan menyesatkan. ${ }^{18}$

Dalam sejarah filsafat Barat, etika adalah cabang filsafat yang amat berpengaruh sejak zaman Socrates (470-399 SM). Etika membahas baik-buruk atau benar-tidaknya tingkah laku dan tidakan manusia serta sekaligus menyoroti kewajiban-kewajiban manusia. Etika tidak mempersoalkan apa atau siapa manusia itu, tetapi bagaimana manusia seharusnya berbuat atau bertindak. Ada berbagai pembagian etika yang dibuat oleh para ahli etika. Beberapa ahli membagi etika kedalam dua bagian, yakni etika deskriptif dan etika normatif. Ada pula yang membagi ke dalam etika normatif dan metaetika. Ahli lain membagi kedalam tiga bagian atau tiga bidang studi, yaitu etika deskriptif, etika normatif, dan metaetika.

18 Ibid., p. 14. 


\section{Etika Deskriptif}

Etika deskriptif menguraikan dan menjelaskan kesadaran dan pengalaman moral secara deskriptif. Ini dilakukan dengan bertolak dari kenyataan bahwa ada berbagai fenomena moral yang dapat digambarkan dan diuraikan secara ilmiah, seperti yang dapat dilakukan terhadap fenomena lainnya, misalnya religi dan seni. Etika deskriptif dapat dibagi ke dalam dua bagian:

Pertama, sejarah moral, yang meneliti cita-cita, aturan-aturan, dan norma-norma moral yang pernah diberlakukan dalam kehidupan manusia pada kurun waktu dan suatu tempat tertentu atau dalam suatu lingkungan besar yang mencakup beberapa bangsa; Kedua, fenomenologi moral, yang berupaya menemukan beberapa makna moralitas dari berbagai fenomena moral yang ada. Fenomenologi moral tidak bermaksud menyediakan petunjuk-petunjuk atau patokan-patokan moral yang perlu dipegang oleh manusia. Karena itu, fenomenologi moral tidak mempermasalahkan apa yang benar dan apa yang salah.

\section{Etika Normatif}

Etika normatif kerap kali juga disebut filsafat moral (moral philosophy) atau juga disebut etika filasafati (philosophical ethics). Etika normatif dapat dibagi ke dalam dua teori, yaitu teori-teori nilai (theories of value) dan teori-teori keharusan (theories of obligation). Teori-teori nilai mempersoalkan sifat kebaikan, sedangkan teori-teori keharusan membahas tingkah laku. Ada pula yang membagi etika normatif ke dalam dua golongan sebagai berikut: konsekuensialis (teleologikal) dan nonkonsekuensialis (deontologikal). Konsekuensialis (teleologikal) berpendapat bahwa moralitas suatu tindakan ditentukan oleh konsekuensinya. Adapun nonkonsekuensialis (deontologikal) berpendapat bahwa moralitas suatu tindakan ditentukan oleh sebab-sebab yang menjadi dorongan dari tindakan itu, atau ditentukan oleh sifat-sifat hakikinya atau oleh keberadaannya yang sesuai dengan ketentuan-ketentuan dan prinsip-prinsip tertentu. Teori-teori nilai (theories of value) bisa bersifat nomistis. Bisa juga bersifat pluralistik. Aliran hedonisme, baik hedonisme spiritualis maupun hedonisme materialistis sensualistis, merupakan salah satu bentuk dan wujud dari teori nilai yang monistis.

Aliran-aliran hedonistis dan nonhedonistis juga dimasukkan ke dalam golongan konsekuensialis atau teleologikal. Aliran utilitarianisme Bentham dan Mill, karena menekankan kebahagian terbesar bagi jumlah yang terbesar, bersifat hedonistis, maka 
masuk ke dalam golongan konsekuensialis atau teleologikal. Adapun aliran utilitarianisme ideal Moore dan Randall masuk ke dalam konsekuesialis atau teleologikal yang nonhedonistis. Demikian juga, aliran perfeksionisme Aritoteles dan Green, yang menekankan perkembangan penuh atau kesempurnaan diri sebagai tujuan akhir yang dapat dicapai oleh manusia, tergolong konsekuensialisme nonhedonistis.

\section{Metaetika}

Metaetika merupakan suatu studi analitis terhadap disiplin etika. Metaetika baru muncul pada abad ke-20, yang secara khusus menyelidiki dan menetapkan arti serta makna, istilah-istilah normatif yang diungkapkan lewat pernyataan-pernyataan etis yang membenarkan atau menyalahkan suatu tindakan. Istilah-istilah normatif yang sering mendapat perhatian khusus, antara lain keharusan, baik, buruk, benar, salah, yang terpuji, yang tidak terpuji, yang adil, yang semestinya, dan sebagainya.

Ada beberapa teori yang disodorkan oleh aliran-aliran yang cukup terkenal dalam metaetika. Teori-teori tersebut ialah teori naturalistis dari naturalisme, teori intuitif dari intuisionisme, teori kongnitivis dari kongnitivisme, teori subjektif dari subjektivisme, teori emotif dari emosivisme, teori imperatif dari imperativisme, dan teori skeptis dari skeptisisme. ${ }^{19}$

Etika tidak hanya berkutat pada hal-hal teoritis, manun juga terkait erat dengan kehidupan konkret, oleh karena itu ada beberapa manfaat etika yang perlu diperhatikan dalam kaitannya dengan kehidupan konkret, yaitu: Perkembangan hidup masyarakat yang semakin pluralistik menghadapkan manusia pada sekian banyak pandangan moral yang bermacam-macam, sehingga diperlukan refleksi kritis dari bidang etika. Contoh; Etika Medis tentang masalah abortus, bayi tabung, Kloning, dan lain-lain.

Selain itu, Gelombang modernisasi yang melanda di segala bidang kehidupan masyarakat, sehingga cara berpikir masyarakat pun ikut berubah. Misalnya: cara berpakaian, kebutuhan fasilitas hidup modern, dan lain-lain. Etika juga menjadikan kita sanggup menghadapi ideologi-ideologi asing yang berebutan mempengaruhi kehidupan kita, agar tidak mudah terpancing. Artinya kita tidak boleh tergesa-gesa memeluk pandangan baru yang belum jelas, namun tidak tidak pula tergesa-gesa menolak pandangan baru lantaran belum terbiasa. Etika diperlukan oleh penganut agama manapun untuk menemukan dasar kemantapan dalam iman dan kepercayaan sekaligus

${ }^{19}$ Hendrik, Pengantar Filsafat, pp. 63-4. 
memperluas wawasan terhadap semua dmensi kehidupan masyarakat yang selalu berubah. $^{20}$

\section{F. Estetika Atau Keindahan}

Berbicara tentang estetika atau keindahan, maka kita menghadapi dua hal, ialah:

1. Pengalaman seni (atau selera),

2. Upaya untuk mengerti tentang keindahan (beauty).

Yang disebut pertama bersifat subyektif, sedangkan yang disebut kedua bersifat obyektif, dan berupaya meningkatkan diri menjadi sains. Namun mengingat sifatnya, ialah kesulitan dengan pengukuran yang eksak dan pembuktian logis (logical proof), mungkin tak akan sampai kesitu. Tanpa rasa tidak ada Etika dan Estetika.

Estetika adalah cabang filsafat yang mempersoalkan seni (art) dan keindahan (beauty). Istilah estetika berasal dari kata Yunani: aisthesis, yang berarti pencerapan indrawi, pemahaman intelektual (intelectual understanding), atau bisa juga berarti pengamatan spiritual. Istilah art (seni) berasal dari kata Latin Ars, yang berarti seni, keterampilan, ilmu, atau kecakapan.

Sejak zaman Yunani purba, estetika filsafati sering disebut dengan berbagai nama, seperti filsafat seni (philosophy of art), filsafat keindahan (philosophy of beauty), filsafat citarasa (philosophy of taste), dan filsafat kritisisme (philosophy of criticism). Akan tetapi, sejak abad ke-18, istilah estetika mulai menggantikan nama-nama tersebut. Istilah estetika diperkenalkan oleh seoarng filsuf Jerman bernama Alexander Gottlieb Baumgarten (17 Juli 1714-26 Mei 1762) lewat karyanya, Meditationes Philosophicae de Nonullis ad Poema Peryinentibus (1735), yang diterjemahkan ke dalam bahasa Inggris dengan judul Reflections on Poetry (1954). Baumgarten mengembangkan filsafat estetika yang didefinisikannya sebagai ilmu pengetahuan tentang keindahan lewat karyanya yang berjudul Aesthetica Acromatica (1750-1758).

Estetika dapat dibagi ke dalam dua bagian, yaitu estetika deskriptif dan estetika normatif. Estetika deskriptif menguraikan dan melukiskan fenomena-fenomena pengalaman keindahan. Estetika normatif mempersoalkan dan menyelidiki hakikat, dasar, dan ukuran pengalaman keindahan. Ada pula yang membagi estetika ke dalam filsafat seni (philosophy of art) dan filsafat keindahan (philosophy of beauty). Filsafat seni

${ }^{20}$ Rizal Mustansyir \& Misnal Munir, Filsafat Ilmu, (Yogyakarta: Pustaka Pelajar, 2001), p. 34. 
mempersoalkan status ontologis dari karya-karya seni dan mempertanyakan pengetahuan apakah yang dihasilkan oleh seni serta apakah yang dapat diberikan oleh seni untuk menghubungkan manusia dengan realitas. Filsafat keindahan membahas apakah keindahan itu dan apakah nilai indah itu objektif atau subjektif.

Ada beberapa pandangan dan pendapat para filsuf tentang masalah estetika ini, antara lain: Plato berpendapat bahwa seni (art) itu adalah keterampilan untuk mereproduksi sesuatu. Bagi Plato, apa yang disebut hasil seni tidak lain dari tiruan (imitation). Sebagai contoh, pelukis yang melukis suatu panorama alam yang indah sesungguhnya hanya meniru panorama alam yang pernah dilihatnya. Dengan demikian, karya-karya seni itu merupakan tiruan yang kedua dan oleh karena itu tidak sesempurna aslinya. Aristoteles sependapat dengan Plato mengenai seni sebagai tiruan dari berbagai hal yang ada. Contoh yang diberikan oleh Aristoteles ialah puisi. Aristoteles mengatakan bahwa puisi adalah tiruan dari tindakan dan perbuatan manusia yang dinyatakan lewat kata-kata. Apabila Plato menganggap bahwa seni itu tidakm begitu penting kendati karya-karya tulisnya merupakan karya seni sastra yang tak tertandingi sampai sekarang ini, Aristoteles justru menganggap bahwa seni itu penting karena memiliki pengaruh yang besar bagi manusia. Aristoteles mengatakan bahwa puisi lebih filsafati daripada sejarah.

Menurut Augustinus, keindahan merupakan salah satu bentuk yang ada dalam pemikiran Allah; oleh sebab itu, keindahan dalam seni dan keindahan dalam alam haruslah memiliki pertalian yang erat dengan agama. Kendati Augustinus mengikuti ajaran Plato tentang keindahan, ia tidak sependapat dengan Plato yang mengatakan bahwa seni hanyalah tiruan. Augustinus mengatakan bahwa hewanpun meniru, tetapi tidak dapat menghasilkan karya seni. David Hume (1711-1776) mengatakan bahwa keindahan bukanlah suatu kaulitas objektif yang terletak di dalam objek-objek itu sendiri, melainkan berada di dalam pikiran. Manusia tertarik pada suatu benda dan struktur tertentu lalu menyebutnya indah. Hume mengatakan bahwa apa yang dianggap indah oleh manusia sesungguhnya amat ditentukan oleh sifat alami manusia, yang dipengaruhi juga oleh kebiasaan dan prefensif individual.

Immanuel Kant (1724-1804) menganggap kesadaran estetis sebagai unsur yang penting dalam pengalaman manusia pada umumnya. Sama seperti Hume, Kant juga berpendapat bahwa keindahan itu merupakan penilaian estetis yang semata-mata 
subjektif. Kant mengatakan bahwa pertimbangan estetis (aesthetic judgment) memberikan fokus yang amat dibutuhkan untuk menjembatani segi-segi teori dan praktek dari sifat dasar manusia.

George Wilhelm Friedrich Hegel (1770-1831) dan Arthur Schopenhauer (17881860) mencoba menyusun tata jenjang bentuk-bentuk seni itu. Bagi Hegel, arsitektur berada pada jenjang paling bawah dan puisi berada di puncaknya. Adapun Schopenhauer menempatkan musik di tempat tertinggi dan arsitektur di tempat terendah.

John Dewey (1859-1952), filsuf Amerika yang dikenal sebagai eksponen pragmatisme, menentang dualisme yang hendak memisah-misahkan segala sesuatu yang seharusnya saling terpaut dan utuh. Dewey berupaya untuk menunjukkan bahwa seni itu sesungguhnya suatu hal yang tak terpisahkan dari kehidupan sehari-hari. Dewey berpendapat bahwa seni terpaut begitu erat dengan segi-segi kehidupan lainnya, maka sangat keliru apabila seni hendak dipisahkan dari segi-segi kehidupan lainnya.

Filsuf Amerika lainnya, George Santayana (1863-1952), mengembangkan estetika naturalistis. Sama seperti Hume dan Kant, Santayana menolak objektivitas keindahan. Menurut Santayana, keindahan identik dengan kesenangan yang dialami manusia ketika ia mengamati objek-objek tertentu. Santayana mengatakan bahwa keindahan itu adalah perasaan senang yang diobjektifkan dan diproyeksikan ke dalam objek yang diamati.

Filsuf Italia, Benedetto Croce (1866-1952), mengembangkan teori estetikanya lewat alam pikiran filsafat idealisme. Croce menyamakan seni dengan intuisi, dan menurut Croce intuisi adalah gambar yang berada di alam pikiran. Dengan demikian, seni itu berada di alam pikiran seniman. Karya sniman dalam bentuk fisik sesungguhnya bukan seni, melainkan semata-mata alat bantu untuk menolong penciptaan kembali seni yang sebenarnya berada di alam pikiran manusia. Croce juga menyamakan intuisi dengan ekspresi. Karena seni sama dengan intuisi dan intuisi sama dengan ekspresi, berarti seni sama dengan ekspresi. Apa yang diekspresikan itu tidak lain dari perasaan si seniman. Croce mengatakan bahwa seni adalah ekspresi dari kesan-kesan (art is expression of impressions).

Clive Bell (1851-1964) mempopulerkan gagasannya lewat ungkapan bentuk yang berarti (significant form) dan perasaan estetis (aesthetic emotion). Yang dimaksudkan dengan bentuk yang berarti ialah hal yang membuat karya-karya seni itu benar-benar bernilai. Perasaan estetis berbeda dengan perasaan-perasaan biasa. Perasaan estetis 
hanya dapat dialami pada saat seseorang sungguh-sungguh menyadari akan bentuk yang berarti. Ia mengatakan bahwa bentuk yang berarti ialah bentuk hasil karya seni yang menggugah perasaan seni seseorang. ${ }^{21}$

Dengan menggunakan ilmu psikologi, keindahan dipandang sebagai kreasi seni dan apresiasi terhadapnya. Pengertian simbolis dan efek emosional daripada citra-citra (images). Di bidang aksiologi dipelajari tentang:

1. Pengetahuan tentang berbagai tipe;

2. Efeknya terhadap berbagai tipe perorangan;

3. Hubungan antara efek dengan nilai dan tujuan (goal).

Sebagai kesimpulan dapat dikatakan bahwa fenomena seni dan selara itu bersifat kompleks dan tidak dapat dipegang (intangible). Banyak yang bersifat unik dan berbeda dari satu kebudayaan ke lain kebudayaan, dan dari waktu ke lain waktu. Karena itu di bidang ini tidak dapat ditegakkan hukum-hukum nomotetik, hanya keberulang-ulangan dan kecenderungan-kecenderungan, asosiasi dan sedikit hubungan kasual. Maka seni sulit untuk bisa menjadi sains (seperti halnya bidang-bidang lain).

\section{G. Extra-Sensory Perception (Non-Observational)}

Extra sensory perception adalah inti dari parapsikologi yang mempelajari pengalaman psikis (psychic experience) yang sering terjadi secara spontan, baik yang bersifat sepele sampai tragis, simpel sampai kompleks, ramalan yang tidak benar sampai khayalan (vision) atau pesan yang tidak kedengaran. Pengalaman-pengalaman itu bisa terjadi ketika bangun atau tidur, kepada tua atau muda, ulama maupun eksekutif bisnis. Bisa menimbulkan efek-efek sensory (subyektif) atau motor (eksternal). Hal-hal tersebut tidak berdiri sendiri, akan tetapi berbaur di dalam pikiran (mind) dengan segala rahasianya.

Ciri-ciri karakteristiknya adalah bahwa kejadian-kejadian itu tidak melalui media fisikal. Pengalaman psikis bertentangan dengan ini semua, misalnya:

1. Memperoleh informasi tentang suatu situasi yang berada dibalik (beyond) kemampuan syaraf psikologis.

2. Mempengaruhi suatu situasi fisik di luar jangkauan tindakan fisik.

${ }^{21}$ Hendrik, Pengantar Filsafat, pp. 68-9. 
Jelas bahwa independensi akan faktor-faktor fisikal itulah yang merupakan karakteristik pengalaman psikis. Maka parapsikologi dapat didefinisikan sebagai ilmu yang mempelajari interaksi-interaksi, baik sensory maupun motor, yang terjadi tanpa mediasi fisikal atau mekanis. Peristiwa-peristiwanya disebut telepati, clairvoyance, precognition, dan psikokinese. Maka kepada otak bisa timbul stimulasi tanpa melalui observasi indrawi. Orang-orang yang berbakat untuk itu termasuk yang ditelaah, dan bisa dicoba pada orang-orang biasa. Ilmu ini sebagian dari psikologi, yang berada pada gugus depan. ${ }^{22}$

\section{H. Ilmu Melalui Pensucian Hati}

Termasuk kedalam mistisisme, seperti sufi atau tasawwuf. Tujuannya adalah mendekatkan diri kepada Tuhan, melalui pensucian hati. Hal ini tidak dapat diterangkan, seperti rasa. Untuk merasakannya, orang harus merasakannya sendiri atau menjalaninya sendiri. Di bidang ilmu hal ini sudah ditempuh oleh Al-Ghazali, yang merasa syak (skeptis), terhadap kemampuan yang bersifat indrawi, yang sering menipu Al-Ghazali mengembara dan menjadi sufi,serta meninggalkan ilmu akal. Beliau dengan cara itu memperoleh ilmu murni, disebut mukasyafah. Dengan cara meditasi, orang memperoleh ilmu langsung dari Tuhan.

Al-Ifafah (memelihara kesucian diri) termasuk ke dalam rangkaian fadlilah atau akhlaqul karimah yang dituntut dalam ajaran Islam. Menjaga diri dari segala keburukan dan memelihara kehormatan hendaklah dilakukan pada setiap waktu. Dengan penjagaan diri secara ketat, maka dapatlah diri dipertahankan untuk selalu berada pada status kesucian. Hal ini dilakukan mulai dari memelihara hati (qalbu) untuk tidak membuat rencana dan angan-angan yang buruk, seperti firman Allah: "Sesungguhnya beruntunglah orang yang mensucikan jiwa itu" (Q.S. 91/ Asy-Syams: 9). ${ }^{23}$

Demikian juga memelihara lidah dan anggota dari segal perbuatan yang tercela, karena sadar bahwa segala gerak-gerik itu tidak lepas dari penglihatan Allah, termasuk akhlaq luhur. Seperti tercantum dalam Firman Allah yang tercantum dalam surat-surat dan ayat-ayat di bawah ini: "yang melihat kamu ketika kamu berdiri (untuk sembahyang), dan (melihat pula) perubahan gerak badanmu di antara orang-orang yang

22 Soewardi, Nalar, Kontemplasi dan Realita, p. 87.

23 Departemen Agama Republik Indonesia, Al-Qur'an dan Terjemahannya, p. 1064. 
sujud", (Q.S. 26/ Asy-Syu'araa: 218-219).24 Selain itu "Dan Dia bersama kamu di mana saja kamu berada. Dan Allah Maha Melihat apa yang kamu kerjakan" (Q.S.57/ Al-Hadiid: 4). ${ }^{25}$ Selanjutnya "Dan Sesungguhnya Kami (Allah) telah menciptakan manusia dan mengetahui apa yang dibisikkan oleh hatinya, dan Kami lebih dekat kepadanya daripada urat lehernya sendiri" (Q.S.50/ Qaf: 16). ${ }^{26}$

Berdasarkan keyakinan bahwa Allah akan mencatat segala gerak tingkahnya, maka orang yang beriman selalu waspada jangan sampai terjerumus ke dalam kemaksiatan yang dimurkai Allah. Sebagai kebalikan dari sikap tersebut ialah sikap memperturutkan panggilan hawa nafsu. Orang yang demikian itu telah menjadi budak dan tawanan hawa nafsunya, sehingga hilanglah kesucian dirinya dan jatuhlah martabat kemuliaannya dan akhirnya akan memperoleh kesesatan dan kerugian yang nyata. Rasulullah SAW, bersabda: "Seorang yang sempurna akal ialah orang yang selalu mengoreksi dirinya dan beramal sebagai bekal untuk mati. Dan orang yang rendah itu ialah orang yang selalu menurutkan hawa nafsunya, di samping itu mempunyai anganangan (yang bukan-bukan) kepada Allah".27

\section{Penutup}

Akal dan naluri manusia adalah anugerah Allah. Akal pikiran manusia terbatas, sehingga pengetahuan manusiapun tidak akan mampu memecahkan seluruh masalah yang maujud ini, sesuai dengan Firman Allah: "Dan tidaklah kamu diberikan pengetahuan, melainkan sedikit sekali" (Q.S. 17/ Al-Isra': 85). Karena itu akal masuh memerlukan bimbingan dan cahaya petunjuk dari sumber kebenaran yang mutlak yang lebih utama, yakni wahyu atau Kitabullah. Hanya akal yang dipancari oleh cahaya AlQur'an dan petunjuk Rasul-Nya akan memperoleh kedudukan yang tepat dan akan dapat menemukan kedudukannya yang benar dan tepat.

Kedudukan naluri dan akal dalam pandangan etika Islam, bahwa keduanya perlu dimanfaatkan dan disalurkan sebaik-baiknya dengan bimbingan dan pengarahan yang ditetapkan dalam Al-Qur'an dan Sunnah Nabi SAW. Sesuai dengan pola hidup yang dianjurkan Islam, bahwa seluruh kegiatan hidup, serta kematian sekalipun, semata-mata

24 Ibid., p. 589.

25 Ibid., p. 900.

26 Ibid., p. 852.

${ }^{27}$ Hadist Riwayat. At-Tirmidzi. 
dipersembahkan kepada Allah SWT. Ucapan yang selalu dinyatakan dalam doa iftitah sholat, merupakan bukti nyata bahwa tujuan yang tertinggi dari segala tingkah laku menurut pandangan etika Islam adalah mendapatkan Ridla Allah SWT (mardlatillah). Ridla Allah itulah yang menjadi kunci kebahagiaan yang kekal dan abadi yang dijanjikan Allah dan yang dirindukan oleh setiap manusia beriman. Tanpa Ridla Allah maka kebahagian abadi dan sejati (surga) tidak akan diraih.

Walaupun berciri khas religius-spiritual, tetapi filsafat Islam juga sangat berpijak atau berpatokan pada akal sehat dalam menafsirkan seluruh permasalahan atau problematika ketuhanan, manusia dan alam, karena wajib alwujud adalah akal nurani. Ia adalah subyek yang berpikir sekaligus obyek pemikiran. Dari-Nya keluar (beremansipasi) akal aktif, karena ia merupakan sesuatu pertama yang diciptakan Allah.

Untuk manusia, Allah juga memberikan Ad-Dinul Islam, yaitu serangkaian kekuatan Tuhan yang diturunkan kepada manusia (yang berupa perintah dan larangan). Ad-Dinul Islam adalah anugerah Allah untuk mengendalikan akal pikiran, perasaan, hati nurani, dan hawa nafsu manusia. Dan sebagai seorang Muslimin, kita diwajibkan untuk: mengimaninya (Ad-Dinul Islam tersebut), mempelajari sedemikian rupa sehingga kita tahu mana yang diperintahkan dan dilarangkan, mengamalkannya, serta menda'wahkan Ad-Dinul Islam tersebut dengan baik dan benar sesuai dengan syariatnya. 


\section{DAFTAR PUSTAKA}

At-Tirmidzi. Hadist Shoheh.

Bakhtiar, Amsal. Filsafat Agama. Jakarta: Logos Wacana Ilmu, 2008.

Baqir, Muhammad, Ash-Shadr. Falsafatuna. Bandung: Mizan, 2008.

Departemen Agama Republik Indonesia. Al-Qur'an dan Terjemahannya. Semarang: CV. Toha Purta, 1999.

Hendrik, Rapar, Jan. Pengantar Filsafat. Yogyakarta: Kanisius, 2005.

Madkour, Ibrahim. Aliran dan Teori Filsafat Islam. Jakarta: Bumi Aksara, 2005.

Mustansyir, Rizal dan Munir, Misnal. Filsafat Ilmu. Yogyakarta: Pustaka Pelajar, 2001.

Nasoetion, Andi, Hakim. Pengantar ke Filsafat Sains. Jakarta: Litera Antar Nusa, 2003.

Salam, Burhanuddin. Pengantar Filsafat. Bandung: Multi Karya Ilmu, 2009.

Soewardi, Herman. Nalar. Kontemplasi dan Realita. Bandung: Unpad, 2005.

Ya'qub, Hamzah. Etika Islam. Pembinaan Akhlaqulkarimah (Suatu Pengantar). Bandung: Diponegoro, 2006. 